\title{
Extracellular Domain
}

National Cancer Institute

\section{Source}

National Cancer Institute. Extracellular Domain. NCI Thesaurus. Code C13458.

Any part of a transmembrane protein that projects into the environment surrounding a cell. 